of the men were unemployed, 11 per cent being employed part time; 86 per cent of the women were employed in housework and 5 per cent had parttime work.

THE commonest leisure activities of this group were reading, card playing, chess and other games and listening to radio. Outdoor activities ranked next, and were preferred by the men, followed by household activities and then hobbies and outdoor sports. 56 per cent of the men and 48 per cent of the women had two hours or less per day of leisure, but about one half had three hours or more. Only 5 per cent of them did no reading each day, but books were read much less regularly than magazines and newspapers. 65 per cent of the men engaged in farming were members of some organization, but three quarters of the others were members of no formal organization. Emphasis was placed upon the provision for social and recreational needs. 28 per cent of the men and 45 per cent of the women wished to travel, but the only other desire expressed by a significant number was to buy or build a home or to own a good farm. The men would welcome opportunity for further training in agriculture and farming, engineering and mechanics. The women emphasized the desirability of training in business subjects, nursing and home economics. Uppermost in the problems of these young persons is the lack of sociability through group relations, and the major need is that of integrating them into a satisfying social life through the development of a consciousness of common social needs and practical local organization to satisfy them.

\section{River Survey}

IN a small pamphlet of a dozen pages ("A Note of the Work of River Flow Records." River Flow Records. 6d.), Capt. W. N. McClean sets out a statement of the work performed by River Flow Records, the private organization of which he is the founder and director, during the period of its existence. The aim of River Flow Records, it is stated, is to obtain, in the area of a river system, records of water-levels of so comprehensive and accurate a character as to enable full information to be deduced therefrom respecting the flow and storage of water. Surveys on these lines have been carried out on the Rivers Garry, Moriston, Foyers, Oich and Ness in the Ness Basin; on the River Arkaig and Muccomer Cut in the Lochy Basin; on the River Spey and on the Aberdeenshire Dee, with results which have been detailed in a series of papers and publications. The pamphlet goes on to discuss several aspects of survey work, including water level stations, flow gauging, rainfall, temperature and wind, the compilation and presentation of records and the analysis and use of records. The author points out the influence of the work and experience gained by River Flow Records in the promotion and institution of an Inland Water Survey for Great Britain, which has been the outcome of a discussion in 1932 at the York meeting of the British Association. There are two appendixes dealing with mechanical details of river survey work.

\section{Herpetologia}

The Chicago Academy of Sciences has sponsored the appearance of a new magazine with the above title, to be devoted to the study of reptiles and amphibians. Parts will appear quarterly, and it is hoped that the issue of such a specialized journal will help to bring together notes and short papers upon reptiles and amphibians which otherwise would be scattered and often unavailable in a multitude of other publications. The defect of such schemes is that they tend to make their particular study more remote from the naturalist who is interested in various groups of animals and endeavours to correlate the biological discoveries in them. From such a general point of view, the most interesting of the papers in the first part of the new magazine is that by $L$. M. Klauber describing and illustrating two varieties of a king snake, one with ringed markings, the other with longitudinal stripes. These have hitherto been regarded as distinct species, Lampropeltis californice and $L$. getulus boylii, but the hatching of broods which contained both forms shows that they are colour varieties of one form, which must be known as L. getulus californice.

\section{Seismology in the United States}

A refort of the Advisory Committee on Seismo. logy appears in the Yearbook for 1935 (pp. 361370) of the Carnegie Institution of Washington. One of the most interesting sections deals with the operations of the Coast and Geodetic Survey during the year ending June 30, 1935. Levelling of the first and second order was carried out over routes with a total length of more than one hundred thousand miles, and triangulation of the first and second order over a length of about 17,500 miles. In California, three arcs of triangulation, altogether 300 miles in length, have been carried out, and eight lines of closely-spaced bench-marks at right angles to well-known and active faults in the State. Five of these lines cross the San Andreas fault, the move. ments along which are responsible for many great Californian earthquakes. Each line extends about five miles on both sides of the faults, the bench marks within the first mile being only $100 \mathrm{ft}$. apart. A short time ago, a network of levels was established in order to study the subsidence of the land round San Jose (Cal.). The levelling was repeated in the autumn of 1934 and the spring of 1935 . Though the work is not yet finished, it is advanced far enough to show that the subsidence noticed in the previous interval of levelling is still continuing.

\section{Mining in South Australia}

WE have received from the Department of Mines in South Australia the mining review for the half. year ended December 31, 1935 (No, 63). It is quite in the usual form; the main matter of interest is contained in the preface, signed by the Director of Mines on April 1, 1936, in which he states that during the year 1935, the mineral production from South Australian mines and quarries exceeded in value that recorded for any previous year ; the total value 
is 45.4 per cent higher than that recorded for 1934 , which was previously the largest total. "The increase in tonnage and in value is due largely to the extraordinary rise in the production of iron ore, which has been the predominant contributor to the total during recent years." This is scarcely surprising since the value of the iron ore raised in 1934 is 84 per cent of the total value of mineral production, the output showing an increase of 50 per cent; most other minerals showed increases, the output of gold being $6 \cdot 7$ per cent greater than that of 1934 . These statements are fairly well borne out by the reports of the Chief Inspector of Mines and the reports of the Inspector of Mines and Quarries attached as usual to this volume.

\section{Scientific Study of Suicide}

A сомміттеE for the study of suicide consisting of ten members including Dr. Henry E. Sigerist, professor of the history of medicine at Johns Hopkins University, and Dr. Edward Sapir, professor of anthropology at Yale University, has recently been incorporated to make a comprehensive study of suicide as a social and psychological phenomenon. The following general outline has been adopted by the Committee : (1) intramural studies of individuals inclined to suicide in selected hospitals for mental diseases ; (2) extramural studies of ambulatory cases with suicidal trends or with obsessional wishes for their own death; (3) social studies of suicide; (4) ethnological studies, that is, comprehensive investigation of suicide among primitive races ; (5) historical studies.

\section{Ministry of Agriculture Leaflets}

Four advisory leaflets have recently been rewritten for the Ministry of Agriculture and Fisheries. No. 267, which replaces the former Leaflet No. 296, deals with "Potato Growing in Allotments and Gardens". The section on autumn preparation of soil directs attention to the importance of taking precautions against wireworms and leather jackets. It is not now recommended that seed be saved from a previous crop grown in the same district, owing to the depredations of virus disease, and the account of manuring is also brought into line with modern research. Advisory Leaflets No. 180, on "The Cultivation of Raspberries", and No. 268, on "Plums and Damsons", are revised mainly in the sections dealing with soils, diseases and manuring. The fourth Leaflet, No. 113, portrays, briefly, but with businesslike adequacy, modern methods of chicken rearing. The descriptions of sanitary considerations reflect modern research findings upon avian disease, the merits of the various systems of hovers and battery brooders are discussed, and the very considerable advances recently made in our knowledge of the food requirements of poultry are very evident in the section on feeding.

\section{World Power Conference}

IN accordance with the constitution of the World Power Conference, which states that the country in which a plenary meeting is held shall appoint the president, Mr. William F. Durand, chairman of the Third World Power Conference, has been appointed to serve until the next plenary meeting. Sir Harold Hartley has been re-elected chairman of the International Executive Council to hold office until the next plenary meeting, and the following have been elected vice-chairmen, to hold office for three years : First Vice-Chairman: Mr. O. C. Merrill (U.S.A.), director of the Third World Power Conference; Second Vice-Chairman: Mr. G. J. T. Bakker, president of the Royal Netherlands Institute of Engineers; Third Vice-Chairman: Dr. M. Kamo, professor in the Faculty of Engineering, Tokyo Imperial University. The Second Chemical Engineering Congress will be held in Berlin in 1940, by invitation of the German National Committee.

\section{Books on Zoology}

Several catalogues of books and periodicals dealing with aspects of biological science have recently appeared. Bernard Quaritch's general catalogue (No. 521) lists all classes of zoological works, to the number of 965 . The most complete section is that dealing with entomology, in which is included a selection of books from the library of the late Robert Adkin. Another of Quaritch's catalogues (No. 524) contains two sections of books on early medicine and surgery, and on early science, in all 83 volumes, most of them belonging to the sixteenth, seventeenth and early eighteenth centuries. Messrs. Wheldon and Wesley's catalogue of books on ornithology (N.S. No. 43) is a useful bibliography of birds, listing 1,289 items, the majority of which are arranged geographically.

\section{The Night Sky in October}

BeTween October 1 and 31 , the days shorten by $1^{\text {h }} 48^{\mathrm{m}}$ in the southernmost part of the British Isles and by $2^{\mathrm{h}} 47^{\mathrm{m}}$ in the northernmost part. British Summer Time ends on Oct. $4^{\mathrm{d}} 2^{\mathrm{h}}$ U.T. The moon is new on Oct. $15^{\mathrm{d}} 10 \cdot 3^{\mathrm{h}}$, and full (the Hunter's Moon) on Oct. $30^{d} 6 \cdot 0^{\mathrm{h}}$. Of the lunar occultations visible from Greenwich, the following may be noted: $v$ Tauri (mag. 4.4) on Oct. $4^{\mathrm{d}} 20^{\mathrm{h}} 43 \cdot 7^{\mathrm{m}}$ as a re. appearance : $\tau$ Tauri (mag. $4 \cdot 3$ ) on Oct. $5^{\mathrm{d}} 3^{\mathrm{h}} 2 \cdot 8^{\mathrm{m}}$ as a disappearance and its subsequent re-appearance at $3^{\mathrm{h}} 44^{\mathrm{m}}$ : A Tauri (mag. $4 \cdot 5$ ) on Oct. $31^{\mathrm{d}} 21^{\mathrm{h}} 56.9^{\mathrm{m}}$ as a disappearance and at $22^{\mathrm{h}} 55 \cdot 7 \mathrm{~m}$ as a reappearance of the star. The planets visible during October are as follows: Mercury as a morning star at greatest west elongation on October 16 : Venus as an evening star in gibbous phase; Jupiter as an evening star. Saturn is visible throughout the night; its ring system appears nearly closed, the minor axis being about 2". The apparent paths of Uranus (stellar magnitude at opposition $6 \cdot 0$ ) and Neptune (mag. $7 \cdot 7$ ) are given in graphical form in the "Handbook" of the British Astronomical Association for 1936 . On October 31, Uranus is in opposition, when its distance from the earth will be about 1,745 millions of miles. Mars is in conjunction with Neptune on October 25, when the former planet will be only 